\title{
POSITIVE EMOTION MEMEDIASI SALES PROMOTION DAN STORE ENVIRONMENT TERHADAP IMPULSE BUYING
}

\author{
Ni Wayan Cynthia Devi ${ }^{1}$ \\ I Made Jatra ${ }^{2}$ \\ ${ }^{1,2}$ Fakultas Ekonomi dan Bisnis Universitas Udayana (Unud), Bali, Indonesia \\ email: Cynthiadevi67@gmail.com
}

\begin{abstract}
ABSTRAK
Impulse buying adalah perilaku konsumen yang melakukan pembelian secara langsung dan tidak ada rencana sebelumnya, dilakukan dengan cepat dan tanpa banyak evaluasi. Perusahaan perlu memperhatikan faktor yang mempengaruhi terciptanya impulse buying untuk meningkatkan pendapatan. Tujuan penelitian untuk mengetahui peran Positive Emotion dalam memediasi sales promotion dan store environment terhadap impulse buying. Penelitian dilakukan di Kota Denpasar dan Alfamart sebagai obyek penelitiannya. Jumlah sampel yang diambil sebanyak 112 responden yang sudah pernah berbelanja di Alfamart. Teknik pengambilan sampel yaitu dengan purposive sampling. Pengumpulan data dilakukan melalui penyebaran kuesioner. Teknik analisis data yang digunakan adalah path analysis. Berdasarkan hasil analisis ditemukan bahwa sales promotion dan store environment berpengaruh positif dan signifikan terhadap Positive Emotion, Positive Emotion berpengaruh positif dan signifikan terhadap impulse buying, sales promotion dan store environment berpengaruh positif dan signifikan terhadap impulse buying, serta Positive Emotion mampu memediasi pengaruh sales promotion dan store environment terhadap impulse buying.
\end{abstract}

Kata kunci : sales promotion, store environment, Positive Emotion, impulse buying.

\begin{abstract}
Impulse buying is the behavior to make purchases directly, without prior plan, done quickly and without much evaluation. Companies need to pay attention to factors that influence the creation of impulse buying to increase revenue. Purpose of this study is to determine Positive Emotion in mediating sales promotion and store environments in impulse buying. Study is conducted in Denpasar and Alfamart as research objects. 112 are used as respondents who had shopped at Alfamart with purposive sampling. Data collected through questionnaires and analyzed using path analysis. Based on the results, sales promotion and store environment have a positive and significant effect on Positive Emotion, Positive Emotion has a positive and significant effect on impulse buying, sales promotion and store environment has a positive and significant effect on impulse buying, and Positive Emotion is able to mediate the influence of sales promotion and store environment for impulse buying.

Keywords: sales promotion, store environment, Positive Emotion, impulse buying.
\end{abstract}




\section{PENDAHULUAN}

Perkembangan keterbukaan pasar dalam globalisasi menyebabkan persaingan bisnis di Indonesia menjadi semakin berkembang pesat dengan banyaknya pengusaha yang terjun ke dalam dunia bisnis, sehingga perusahaan dituntut untuk mampu memenangkan persaingan melalui penerapan strategistrategi pemasaran yang tepat. Salah satu bisnis yang mengalami perkembangan di Indonesia adalah bisnis ritel. Utami (2010:5) menjelaskan ritel atau pengecermerupakan aktivitas bisnis yang melakukan penjualan barang atau jasa secara langsung kepada konsumen akhir untuk keperluan pribadi dan bukan untuk penggunaan binis. Perkembangan bisnis ritel di Indonesia disebabkan karena mulai bergesernya perilaku berbelanja masyarakat dari pasar tradisional menuju ritel modern. Ritel modern seperti hypermarket, minimarket, supermarket, department store, factory outlet dan lainnya mampu memberikan kenyamanan serta kemudahan saat berbelanja dan juga kecepatan pelayanan yang menjadikan bisnis ritel di Indonesia semakin berkembang. Minimarket merupakan ritel yang menjual jenis dan item produk yang terbatas, tempat berbelanja yang nyaman serta jam buka yang panjang. Perkembangan minimarket di Indonesia menyebabkan adanya persaingan yang ketat untuk meningkatkan omset penjualan pada setiap periodenya.

Impulse buying adalah perilaku konsumen yang melakukan pembelian secara langsung dan tidak ada rencana sebelumnya yang dilakukan dengan cepat dan tidak memerlukan banyak evaluasi (Temaja dkk., 2015). Pembelian secara tidak terencana tersebut diakibatkan oleh adanya Positive Emotion (emosi positif) yang dirasakan oleh konsumen (Idris, 2018). Positive Emotion dapat diartikan sebagai suasana hati yang dirasakan seseorang yang mempengaruhi pengambilan keputusan yang cenderung mengurangi kompleksitas dan waktu dalam pengambilan keputusan saat melakukan pembelian (Sudarsono, 2017). Konsumen dalam keadaan emosi positif lebih cenderung terlibat dalam perilaku pendekatan daripada penghindaran. Emosi yang positif tersebut dapat muncul diakibatkan oleh terpenuhinya kebutuhan ataupun keinginan dari seseorang tersebut. Emosi positif yang dirasakan seseorang dapat menimbulkan perilaku pembelian yang tidak terencana karena timbulnya perasaan gembira atau senang yang dipengaruhi oleh berbagai lingkungan yang dapat mendorong perilaku pembelian tidak terencana tersebut. Untuk memunculkan Positive Emotion dapat dilakukan dengan melakukan promosi penjualan (Darmayasa dan Sukaatmadja, 2017). Penawaran yang diberikan dapat berupa potongan harga, gift, kupon, undian berhadiah, dan lain sebagainya untuk menarik perhatian konsumen. Selain promosi penjualan, lingkungan toko (store environment) juga dapat membangun emosi positif konsumen. Sebuah gerai ritel harus memperhatikan penciptaan lingkungan gerai dalam menjalankan peluang bisnis ritel modern. Lingkungan toko adalah faktorfaktor situasional yang dapat mempengaruhi perilaku impulse buying. Lingkungan belanja yang nyaman dapat memberikan nilai tambah yang mampu membuat konsumen lebih lama berada di dalam gerai sehingga memicu terjadinya pembelian. (Dewi dan Giantari, 2015). 


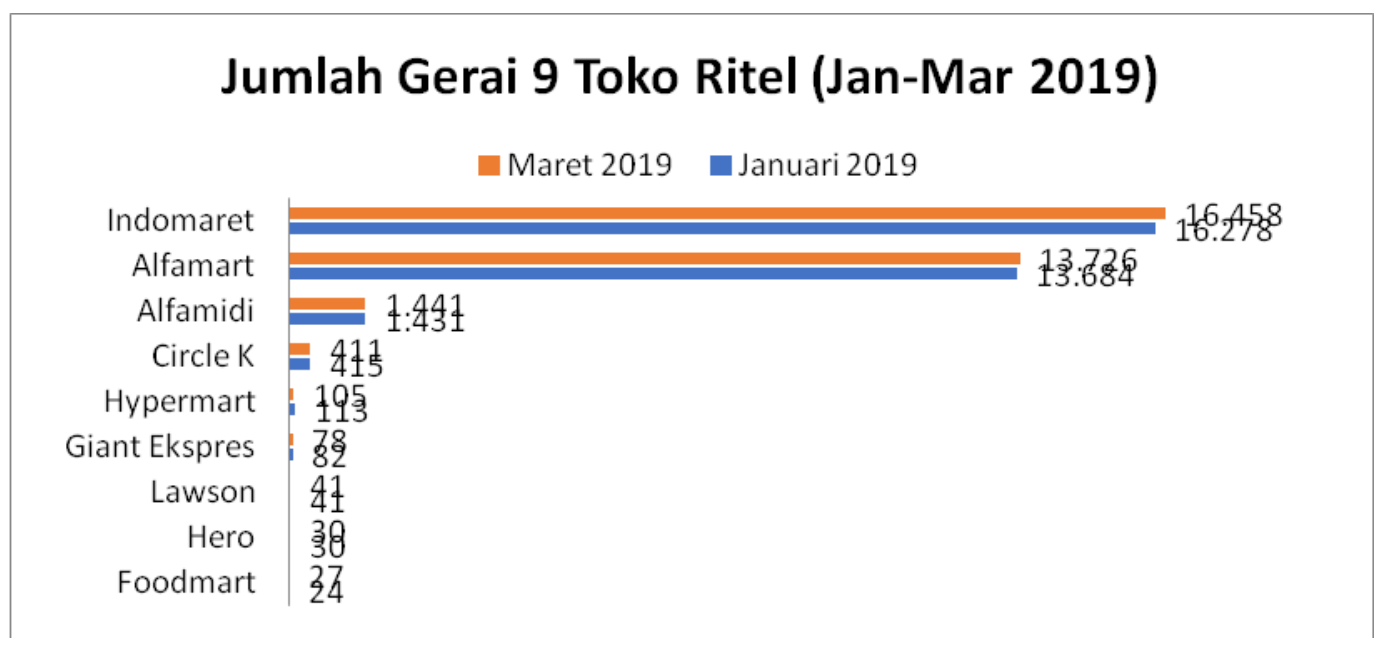
Sumber : Data Diolah, 2019

Terlihat dari jumlah gerai Indomaret dan Alfamart yang berada pada posisi teratas dibandingkan dengan Alfamidi, Circle K, Hypermart, Giant Ekspres, Lawson, Hero, dan Foodmart. Dengan konsep lebih mendekatkan ke konsumen, Alfamart dan Indomaret mampu memenangi pasar minimarket di Indonesia. Berdasarkan Gambar 1. menunjukkan bahwa gerai Alfamart meningkat menjadi 13.726 unit dari posisi Januari 2019 sebanyak 13.684 unit. Demikian pula dengan Indomaret yang jumlah gerainya bertambah pada Maret 2019 dibandingkan dengan Januari 2019. Dari sisi penjualan antara Alfamart dan Indomaret periode 2014 sampai dengan 2018 dapat dilihat pada Gambar 2.

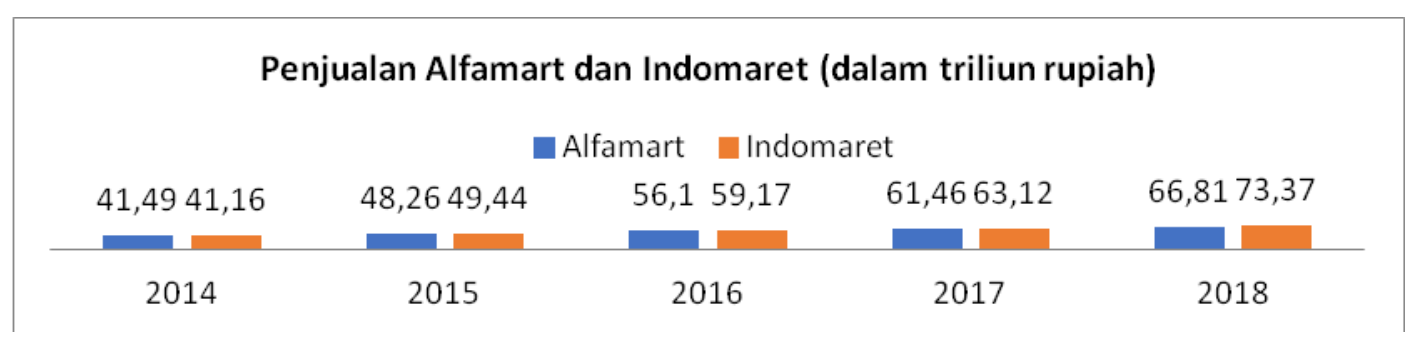

Gambar 2. Kinerja Penjualan Alfamart dan Indomaret (2014-2018) Sumber : Data Diolah, 2019

Berdasarkan Gambar 2. dapat dilihat bahwa penjualan Alfamart dan Indomaret periode 2014 sampai dengan 2018 sama-sama mengalami kenaikan penjualan setiap tahunnya. Pada tahun 2014, penjualan Indomaret mencapai Rp41,16 triliun sementara Alfamart meraup penjualan yang lebih besar yaitu Rp41,49 triliun. Namun pada tahun 2015 sampai dengan 2018, kondisinya menjadi berbeda dimana penjualan Indomaret menjadi lebih unggul dari Alfamart. Pada tahun 2018 penjualan Indomaret mencapai Rp73,37 triliun sedangkan penjualan Alfamart lebih kecil dari Indomaret yaitu sebesar Rp66,81 triliun. Maka dari itu, untuk meningkatkan penjualan dan unggul dari Indomaret ada beberapa strategi yang dapat dilakukan oleh Alfamart diantaranya yaitu melakukan promosi 
penjualan dan membuat lingkungan toko yang nyaman. Promosi penjualan yang gencar serta lingkungan toko yang dibuat nyaman dapat membangun emosi positif dari konsumen sehingga dapat meningkatkan perilaku pembelian tidak terencana dari konsumen. Semakin banyak konsumen yang melakukan pembelian secara tidak terencana, maka dapat meningkatkan penjualan dari Alfamart yang nantinya bisa membuat Alfamart menjadi lebih unggul dari Indomaret dari sisi penjualan dan juga jumlah gerainya.

Idris (2018) menunjukkan bahwa promosi penjualan berpengaruh positif terhadap pembelian impulsif. Akan tetapi, penelitian yang dilakukan oleh Jauhari (2017) menemukan hasil bahwa promosi penjualan berpengaruh negatif terhadap impulse buying. Husnain et al. (2019) menyatakan bahwa lingkungan toko memiliki pengaruh yang positive signifikan terhadap impulse buying. Penelitian yang dilakukan oleh Idris (2018) menyatakan bahwa promosi penjualan memiliki pengaruh yang positif dan signifikan terhadap emosi positif. Sedangkan, penelitian yang dilakukan oleh Diany dkk. (2019) menyatakan bahwa promosi penjualan tidak berpengaruh signifikan terhadap Positive Emotion. Suwandi dan Soelasih (2014) menemukan bahwa terdapat pengaruh positif lingkungan toko terhadap pembentukan emosi positif konsumen. Namun, penelitian yang dilakukan oleh Chang et al. (2015) menemukan bahwa karakteristik sosial dari lingkungan toko tidak berpengaruh terhadap emosi positif konsumen.

Tabel 1.

Pra Survei Penelitian Alfamart di Kota Denpasar

\begin{tabular}{|c|c|c|c|}
\hline \multirow[t]{2}{*}{ No } & \multirow[t]{2}{*}{ Pernyataan } & \multicolumn{2}{|c|}{ Jumlah Responden } \\
\hline & & Ya & Tidak \\
\hline 1 & $\begin{array}{l}\text { Ketika berkunjung ke Alfamart, saya membeli produk walau } \\
\text { tidak direncanakan sebelumnya }\end{array}$ & 22 & 8 \\
\hline 2 & $\begin{array}{l}\text { Ketika berkunjung ke Alfamart, saya tidak dapat menolak saat } \\
\text { ada tawaran yang menarik }\end{array}$ & 20 & 10 \\
\hline 3 & $\begin{array}{l}\text { Ketika berkunjung ke Alfamart, saya merasa senang saat } \\
\text { melakukan pembelian yang tidak direncanakan sebelumnya }\end{array}$ & 18 & 12 \\
\hline
\end{tabular}

Sumber: Data Diolah, 2019

Pra-survei dilakukan peneliti untuk mengetahui fenomena pembelian secara tidak terencana yang terjadi pada konsumen Alfamart di Kota Denpasar. Prasurvei penelitian ini dilakukan dengan cara menyebar kuesioner kepada 30 responden yang sudah pernah berbelanja di Alfamart. Hasil pra-survei dari pernyataan nomor satu "Ketika berkunjung ke Alfamart, saya membeli produk walau tidak direncanakan sebelumnya" dua puluh dua responden menjawab ya membeli produk walau tidak direncanakan sebelumnya dan delapan responden menjawab tidak. Pernyataan nomor dua "Ketika berkunjung ke Alfamart, saya tidak dapat menolak saat ada tawaran yang menarik" menunjukkan dua puluh responden menjawab ya tidak dapat menolak tawaran yang menarik dan sepuluh responden menjawab tidak. Pernyataan nomor tiga "Ketika berkunjung ke Alfamart, saya merasa senang saat melakukan pembelian yang tidak direncanakan sebelumnya" delapan belas responden menjawab ya merasa senang sedangkan dua belas responden menjawab tidak. 
Penelitian yang dilakukan oleh Akyuz (2018) dan Nishanov dan Ahunjonov (2016) menyatakan bahwa sales promotion berpengaruh positif signifikan terhadap impulse buying. Hasil penelitian tersebut juga didukung oleh Idris (2018), Ismail dan Siddiqui (2019), Kasimin dkk. (2015), Pradipta dan Rastini (2014), Mamuaya dan Pandowo (2018), Maulana (2018) serta Negara dan Kusumadewi (2018). dimana promosi penjualan berpengaruh positif terhadap pembelian impulsif. Promosi penjualan memiliki pengaruh langsung sehingga perusahaan harus meningkatkan strategi untuk memasarkan dan menggencarkan promosi penjualan agar pembelian secara tidak terencana juga ikut meningkat.

$\mathrm{H}_{1}$ : Sales promotion berpengaruh positif dan signifikan terhadap impulse buying.

Menurut penelitian yang dilakukan oleh Nindyakirana dan Maftukhah (2016) ditemukan hasil bahwa terdapat pengaruh secara langsung lingkungan toko terhadap impulse buying yang berarti semakin tinggi lingkungan toko diterapkan maka dapat meningkatkan impulse buying. Penelitian tersebut juga didukung oleh Jhawar dan Kushwaha (2018) yang menyatakan bahwa suasana lingkungan di dalam toko mempengaruhi pembelian impulsif. Hasil penelitian ini juga didukung oleh Saad dan Metawie (2015), Husnain et al. (2019), Prakash dan Sharma (2016), serta Purwa dan Yasa (2014).

$\mathrm{H}_{2}$ :Store Environment berpengaruh positif dan signifikan terhadap impulse buying

Hasil penelitian dari Idris (2018), menyatakan bahwa promosi penjualan berpengaruh positif dan signifikan terhadap emosi positif. Hal ini didukung juga oleh hasil penelitian dari Akyuz (2018) serta Suwandi dan Soelasih (2014) yang menyatakan bahwa semakin ditingkatkannya promosi penjualan maka akan dapat meningkatkan emosi positif konsumen yang nantinya akan melakukan pembelian secara impulsif atau tidak terencana.

$\mathrm{H}_{3}$ : Sales Promotion berpengaruh positif dan signifikan terhadap Positive Emotion.

Menurut penelitian yang dilakukan oleh Suwandi dan Soelasih (2014) terdapat pengaruh positif lingkungan toko terhadap pembentukan emosi positif konsumen. Volume musik dan aroma yang terdapat di dalam toko dapat meningkatkan emosi pembeli dan juga meningkatkan kepuasan konsumen (Abimnwi dan Njuguna, 2015). Hasil penelitian ini juga didukung oleh Margana dan Setiawan (2014), Nindyakirana dan Maftukhah (2016) Putra dan Sukawati (2015).

$\mathrm{H}_{4}$ : Store environment berpengaruh positif dan signifikan terhadap Positive Emotion.

Hasil penelitian yang dilakukan oleh Darmayasa dan Sukaatmadja (2017), Akyuz (2018), Margana dan Setiawan (2014) serta Gumilang dan Nurcahya (2016) menunjukkan bahwa emotional shopping berpengaruh positif dan signifikan terhadap impulse buying behavior, hal ini berarti semakin terciptanya emotional shopping yang positif maka akan semakin meningkatnya perilaku impulse buying.

$\mathrm{H}_{5}$ : Positive Emotion berpengaruh positif dan signifikan terhadap impulse buying

Suasana hati akan mempengaruhi dan menentukan intensitas belanja, sehingga dengan suasana hati yang positif maka konsumen akan cenderung lebih berbelanja dengan hal-hal yang tidak direncanakan sebelumnya. Promosi 
penjualan yang dilakukan di dalam toko dapat meningkatkan suasana hati yang baik ketika konsumen melakukan pembelian (Chih-Yi dan Chien-Ping, 2016). Penelitian yang dilakukan oleh Negara dan Kusumadewi (2018), Maulana (2018) serta Nindyakirana dan Maftukhah (2016). menemukan bahwa emosi positif secara signifikan berhasil memediasi hubungan antara sales promotion terhadap impulse buying.

$\mathrm{H}_{6}$ : Positive Emotion berpengaruh positif dan signifikan dalam memediasi Sales Promotion terhadap impulse buying

Menurut Putra dan Sukawati (2015), Purwa dan Yasa (2014), Negara dan Kusumadewi (2018), Maulana (2018), Margana dan Setiawan (2014) Emotional Response berpengaruh signifikan dalam memediasi Store Environment terhadap Impulse Buying. Hal ini berarti konsumen lebih besar kemungkinan melakukan pembelian secara impulsive ketika konsumen tersebut termotivasi oleh stimulusstimulus dari lingkungan toko seperti aroma ruangan yang haru, tata ruang yang rapi, dan suara music yang enak didengar.

$\mathrm{H}_{7}$ : Positive Emotion berpengaruh positif dan signifikan dalam memediasi Store Environment terhadap impulse buying

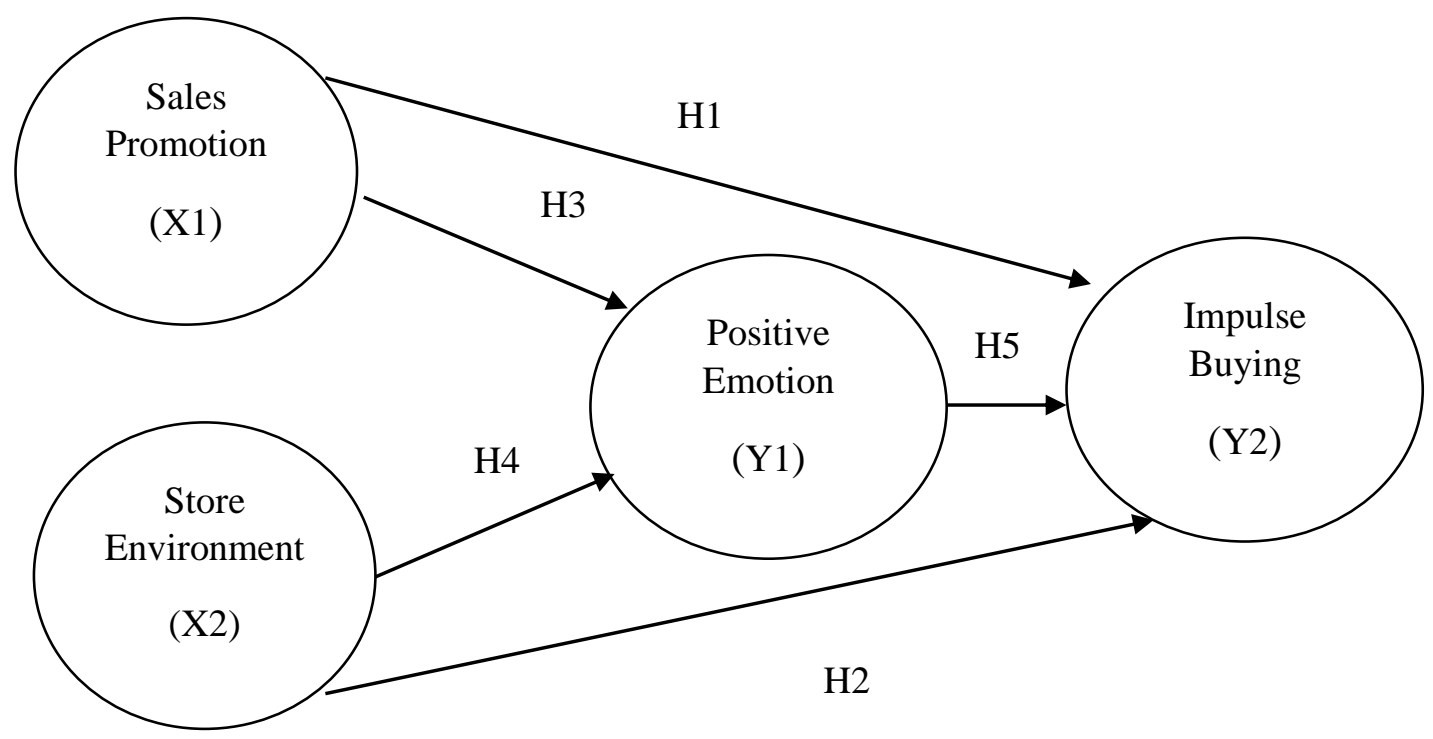

Gambar 3. Kerangka Konseptual Penelitian

\section{METODE PENELITIAN}

Jenis penelitian ini merupakan penelitian asosiatif kausal dengan teknik analisis kuantitatif. Penelitian ini dilakukan di Kota Denpasar. Kota Denpasar dipilih menjadi lokasi penelitian karena Kota Denpasar merupakan Ibu Kota Provinsi Bali dengan penduduk terbanyak diantara wilayah lain di Bali. Kota Denpasar juga memiliki tingkat konsumsi per kapita tertinggi dibandingkan dengan wilayah lainnya. Tingkat konsumsi yang tinggi mengindikasikan bahwa besarnya daya beli masyarakat Kota Denpasar terhadap suatu produk.

Sales promotion (promosi penjualan) dalam penelitian ini merupakan kegiatan yang dilakukan oleh perusahaan yang bertujuan untuk menarik 
konsumen dengan memberikan penawaran yang menarik agar konsumen melakukan pembelian di Alfamart. Mengukur promosi dengan 4 indikator yang diadaptasi dari penelitian yang dilakukan oleh Maulana (2018) serta Negara dan Kusumadewi (2018) sebagai berikut : 1) Member card adalah kartu yang digunakan untuk keperluan yang berhubungan dengan keanggotaan dari sebuah perusahaan atau organisasi tertentu $\left(\mathrm{X}_{1.1}\right)$ 2) Cash back adalah penawaran yang diberikan kepada konsumen berupa uang tunai atau uang virtual dengan memenuhi syarat pembelian tertentu yang sudah ditentukan oleh pihak penyelenggara cashback $\left(\mathrm{X}_{1.2}\right)$ 3) Beli dua gratis satu adalah strategi penawaran yang diberikan kepada konsumen untuk menarik minat membeli dengan memberikan promo beli dua mendapat gratis satuitem produk $\left(\mathrm{X}_{1.3}\right)$ 4) Diskon adalah strategi penawaran berupa potongan harga yang diberikan kepada konsumen untuk menarik minat konsumen dalam membeli produk $\left(\mathrm{X}_{1.4}\right)$

Store environment (lingkungan toko) dalam penelitian ini merupakan semua hal yang berkaitan dengan desain toko, tata letak, warna, pencahayaan dan aroma yang dapat menarik minat konsumen dalam menciptakan kesan yang baik. Mengukur store environment dengan 4 indikator yang diadaptasi dari penelitian yang dilakukan oleh Rahmadi (2014), Hendra (2019), serta Indrawan dan Sudiksa (2019) yaitu : 1) Penataan ruang adalah proses perencanaan tata ruang, pemanfaatan tata ruang, dan pengendalian pemanfaatan ruang agar konsumen mudah dalam mencari barang yang diinginkan $\left(X_{2.1}\right)$ 2) Penataan cahaya adalah tata cahaya yang berfungsi untuk menerangi ruangan dan membuat suasana yang nyaman serta membangun estetika pada ruangan $\left(X_{2.2}\right) 3$ ) Musik adalah nada atau suara yang disusun sehingga mengandung irama, lagu, dan keharmonisan terutama suara yang dihasilkan dari alat-alat yang dapat menghasilkan irama $\left(\mathrm{X}_{2.3}\right)$ 4) Aroma adalah rasa yang berupa wewangian yang ada di dalam gerai untuk menambah kenyamanan saat konsumen berbelanja $\left(\mathrm{X}_{2.4}\right)$

Positive Emotion (emosi positif) dalam penelitian ini merupakan perasaan senang, gembira, suka, tenang, dan kepuasan yang dirasakan oleh konsumen. Mengukur Positive Emotion dengan 4 indikator yang diadaptasi dari penelitian yang dilakukan oleh Choirul dan Artanti (2019), Maulana (2018) dan Negara dan Kusumadewi (2018): 1) Merasa bersemangat adalah perasaan semangat yang muncul pada diri seseorang saat berbelanja di dalam toko ( $\left.Y_{1.1}\right)$ 2) Merasa puas adalah perasaan puas yang muncul pada diri seseorang saat berbelanja di dalam toko $\left(\mathrm{Y}_{1.2}\right)$ 3) Merasa senang adalah perasaan senang yang muncul pada diri seseorang saat berbelanja di dalam toko( $\left.\mathrm{Y}_{1.3}\right)$ 4) Merasa nyaman adalah perasaan nyaman yang muncul pada diri seseorang saat berbelanja di dalam toko $\left(\mathrm{Y}_{1.4}\right)$

Impulse buying dalam penelitian ini merupakan perilaku pembelian yang dilakukan oleh konsumen tanpa adanya perencanaan terlebih dahulu. Mengukur impulse buying dengan 4 indikator yang diadaptasi dari penelitian Diany et al., (2019), Hendra (2019) dan Maulana (2018) sebagai berikut : 1) Pembelian tanpa direncanakan adalah keadaan dimana konsumen membeli produk tanpa direncanakan sebelumnya saat berada di dalam toko $\left(\mathrm{Y}_{2.1}\right)$ 2) Tidak dapat menolak keinginan untuk berbelanja adalah keadaan dimana konsumen tidak dapat menolak keinginan untuk berbelanja karena ada tawaran yang menarik saat berada di dalam toko $\left(\mathrm{Y}_{2.2}\right) 3$ ) Merasa senang saat melakukan pembelian tidak terencana 
adalah keadaan dimana timbul perasaan senang saat melakukan pembelian yang tidak direncanakan sebelumnya $\left(\mathrm{Y}_{2.3}\right)$ 4) Pembelian walau tidak sesuai keinginan adalah konsumen membeli produk walaupun tidak sesuai dengan keinginan yang pembeliannya diakibatkan oleh adanya penawaran yang menarik saat berada di dalam toko $\left(\mathrm{Y}_{2.4}\right)$

Data primer yang digunakan dalam penelitian ini diperoleh dari jawaban responden terhadap pernyataan kuesioner yang dikumpulkan dari konsumen Alfamart di Kota Denpasar. Populasi dari penelitian ini adalah seluruh konsumen Alfamart di Kota Denpasar yang sudah pernah membeli produk yang dijual di Alfamart dengan responden sebanyak 112 orang yang sudah dapat dikatakan cukup untuk membuktikan hasil penelitian ini. Penelitian ini menggunakan metode pemilihan sampel non-probability sampling dengan menggunakan teknik purposive sampling.

\section{HASIL DAN PEMBAHASAN}

Tabel 2.

Karakteristik Responden

\begin{tabular}{|c|c|c|c|c|}
\hline No & Variabel & Klasifikasi & $\begin{array}{l}\text { Jumlah } \\
\text { (orang) }\end{array}$ & $\begin{array}{c}\text { Persentase } \\
(\%)\end{array}$ \\
\hline \multirow{3}{*}{1} & \multirow{3}{*}{$\begin{array}{c}\text { Jenis } \\
\text { Kelamin }\end{array}$} & Laki - Laki & 32 & 28.6 \\
\hline & & Perempuan & 80 & 71.4 \\
\hline & & Jumlah & 112 & 100 \\
\hline \multirow{4}{*}{2} & \multirow{3}{*}{ Usia } & 18-23 Tahun & 87 & 77.7 \\
\hline & & 24-29 Tahun & 21 & 18.8 \\
\hline & & >30Tahun & 4 & 3.6 \\
\hline & \multirow{5}{*}{$\begin{array}{c}\text { Pendidikan } \\
\text { terakhir }\end{array}$} & Jumlah & 112 & 100 \\
\hline \multirow{4}{*}{3} & & SMA & 53 & 47.3 \\
\hline & & Diploma & 30 & 26.8 \\
\hline & & $\mathrm{S} 1$ & 27 & 24.1 \\
\hline & & Pasca sarjana & 2 & 1.8 \\
\hline \multirow{6}{*}{4} & \multirow{6}{*}{ Pekerjaan } & Jumlah & 112 & 100 \\
\hline & & Pelajar & 46 & 41.1 \\
\hline & & PegawaiSwasta & 21 & 18.8 \\
\hline & & PNS & 6 & 5.4 \\
\hline & & Wiraswasta & 39 & 34.8 \\
\hline & & Jumlah & 112 & 100 \\
\hline
\end{tabular}

Berdasarkan Tabel 2. dapat dilihat jumlah pelanggan pada Konsumen Alfamart di Kota Denpasar yang di jadikan sampel sebanyak 112 orang. Jika di lihat dari jenis kelamin, jenis kelamin perempuan mendominasi dalam penelitian ini yakni 80 orang atau 71,4 persen. Sedangkan responden dengan jenis kelamin laki-laki sebanyak 32 orang atau 28,6 persen. Berdasarkan karakteristik usia, responden dengan usia 18-23 tahun yang paling mendominasi diantara usia lainnya yakni 87 orang atau 77,7 persen. Sedangkan responden dengan usia $>30$ tahun yang paling sedikit yakni sebanyak 4 orang atau 3,6 persen. Berdasarkan karakteristik pendidikan, responden dengan tingkat pendidikan terakhir SMA 
yang mendominasi diantara tingkat pendidikan lainnya yakni sebanyak 53 orang atau 47,3 persen. Sedangkan responden yang paling sedikit adalah responden dengan tingkat pendidikan Pasca Sarjana yakni 2 orang atau 1,8 persen. Berdasarkan karakteristik pekerjaan, responden dengan pekerjaan sebagai pelajar atau mahasiswa yang mendominasi diantara tingkat pekerjaan lainnya yakni sebanyak 46 orang atau 41,1 persen. Sedangkan responden yang paling sedikit adalah responden dengan pekerjaan Pegawai Negri Sipil yakni 6 orang atau 5,4 persen.

Tabel 3.

\section{Hasil Uji Validitas}

\begin{tabular}{|c|c|c|c|}
\hline No. & Variabel & Instrumen & $\begin{array}{c}\text { Pearson } \\
\text { Correlation }\end{array}$ \\
\hline \multirow{5}{*}{1.} & \multirow{5}{*}{ Sales promotion $(\mathrm{X} 1)$} & $\mathrm{X} 1.1$ & 0,563 \\
\hline & & $\mathrm{X} 1.2$ & 0,689 \\
\hline & & $\mathrm{X} 1.3$ & 0,774 \\
\hline & & X1.4 & 0,743 \\
\hline & & $\mathrm{X} 2.1$ & 0,551 \\
\hline \multirow{4}{*}{2.} & \multirow{4}{*}{ Store environment (X2) } & $\mathrm{X} 2.2$ & 0,581 \\
\hline & & $\mathrm{X} 2.3$ & 0,769 \\
\hline & & $\mathrm{X} 2.4$ & 0,733 \\
\hline & & Y1.1 & 0,580 \\
\hline \multirow[t]{4}{*}{3.} & Positive Emotion (Y1) & Y1.2 & 0,768 \\
\hline & & Y1.3 & 0,876 \\
\hline & & Y1.4 & 0,853 \\
\hline & & Y2.1 & 0,735 \\
\hline \multirow[t]{3}{*}{4.} & Impluse buying (Y) & Y2.2 & 0,916 \\
\hline & & Y2.3 & 0,893 \\
\hline & & Y2.4 & 0,861 \\
\hline
\end{tabular}

Sumber : Data Diolah, 2019

Tabel 4.

Uji Reliabilitas

\begin{tabular}{llc}
\hline No. & \multicolumn{1}{c}{ Variabel } & Cronbach's Alpha \\
\hline 1. & Sales promotion $(\mathrm{X} 1)$ & 0,643 \\
2. & Store environment $(\mathrm{X} 2)$ & 0,678 \\
3. & Positive Emotion $(\mathrm{Y} 1)$ & 0,782 \\
4. & Impluse buying $(\mathrm{Y} 2)$ & 0,875 \\
\hline
\end{tabular}

Sumber : Data Diolah, 2019

Seluruh instrumen variabel penelitian berupa sales promotion, store environment, Positive Emotion dan impulse buying telah memenuhi syarat uji validitas dan memenuhi syarat reliabilitas.

Berdasarkan Tabel 5. pernyataan yang memiliki rata-rata terendah dari variabel Sales promotion adalah "Saya merasa kartu belanja anggota (member card) dari Alfamart sudah berfungsi secara efektif”, memiliki nilai rata-rata yang rendah dibandingkan dengan pernyataan yang lainnya ini berarti secara umum responden menganggap kartu belanja anggota (member card) dari Alfamart belum berfungsi secara efektif. Nilai rata-rata tertinggi adalah pernyataan "Saya tertarik 
dengan promosi beli dua gratis satu yang diberikan Alfamart.”, diperoleh nilai rata-rata sebesar 4,22 yang masuk kriteria baik, ini berarti secara umum responden tertarik dengan promosi beli dua gratis satu yang diberikan Alfamart.

\section{Tabel 5.}

Deskripsi Jawaban Responden Terhadap Sales promotion

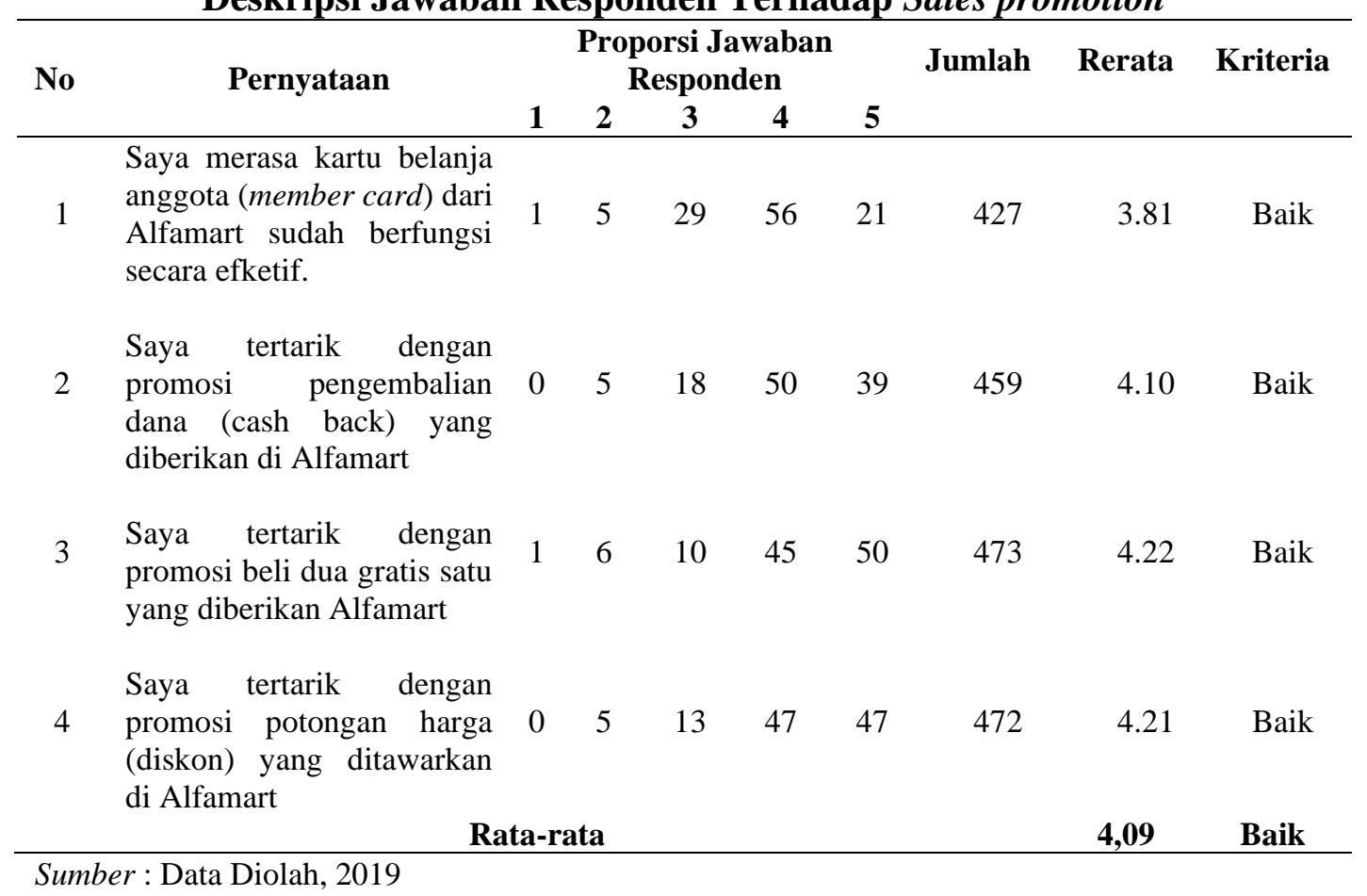

Tabel 6.

Deskripsi Jawaban Responden Terhadap Store Environment

\begin{tabular}{|c|c|c|c|c|c|c|c|c|c|}
\hline \multirow[t]{2}{*}{ No } & \multirow[t]{2}{*}{ Pernyataan } & \multicolumn{5}{|c|}{$\begin{array}{c}\text { Proporsi Jawaban } \\
\text { Responden }\end{array}$} & \multirow[t]{2}{*}{ Jumlah } & \multirow[t]{2}{*}{ Rerata } & \multirow[t]{2}{*}{ Kriteria } \\
\hline & & 1 & 2 & 3 & 4 & 5 & & & \\
\hline 1 & $\begin{array}{l}\text { Penataan produk di } \\
\text { Alfamart memudahkan } \\
\text { dalam mencari produk } \\
\text { yang saya inginkan }\end{array}$ & 0 & 1 & 23 & 61 & 27 & 450 & 4.02 & Baik \\
\hline 2 & $\begin{array}{l}\text { Penataan cahaya di } \\
\text { dalam gerai Alfamart } \\
\text { tampak terang }\end{array}$ & 0 & 4 & 19 & 51 & 38 & 459 & 4.10 & Baik \\
\hline 3 & $\begin{array}{l}\text { Musik yang diputar di } \\
\text { Alfamart menimbulkan } \\
\text { rasa nyaman saat } \\
\text { berbelanja }\end{array}$ & 1 & 10 & 38 & 44 & 19 & 406 & 3.63 & Baik \\
\hline
\end{tabular}

Bersambung... 
Lanjutan Tabel 6.

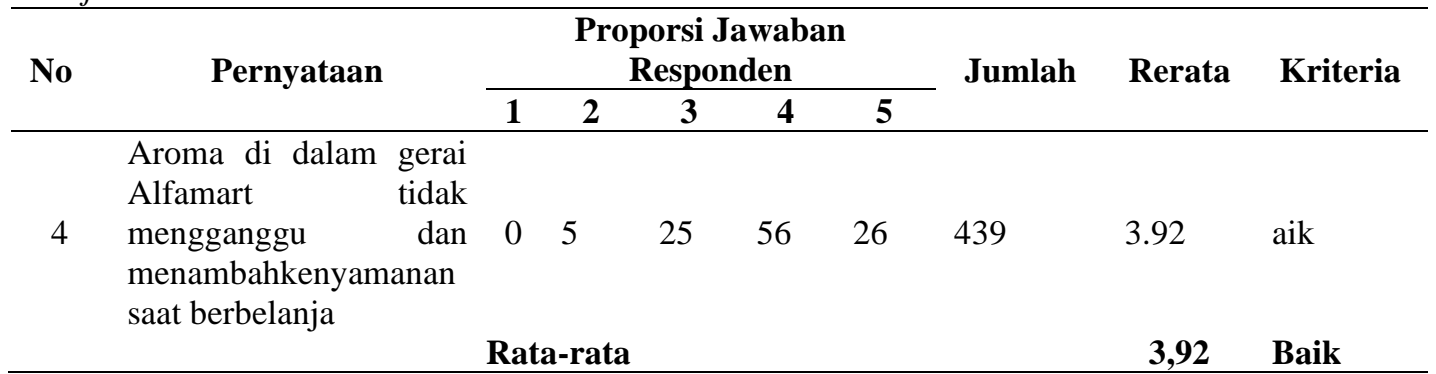

Sumber: Data Diolah, 2019

Berdasarkan Tabel 6. pernyataan yang memiliki rata-rata terendah dari variabel Store environment adalah "Musik yang diputar di Alfamart menimbulkan rasa nyaman saat berbelanja", berarti secara umum responden menganggap musik yang diputar di Alfamart belum menimbulkan rasa nyaman saat berbelanja. Nilai rata-rata tertinggi adalah pernyataan "Penataan cahaya di dalam gerai Alfamart tampak terang", diperoleh nilai rata-rata sebesar 4,10 yang masuk kriteria cukup baik, ini berarti secara umum responden menganggap penataan cahaya di dalam gerai Alfamart sudah tampak terang.

Tabel 7.

Deskripsi Jawaban Responden Terhadap Positive Emotion

\begin{tabular}{|c|c|c|c|c|c|c|c|c|c|}
\hline \multirow[t]{2}{*}{ No } & \multirow[t]{2}{*}{ Pernyataan } & \multicolumn{5}{|c|}{$\begin{array}{l}\text { Proporsi Jawaban } \\
\text { Responden }\end{array}$} & \multirow[t]{2}{*}{ Jumlah } & \multirow[t]{2}{*}{ Rerata } & \multirow[t]{2}{*}{ Kriteria } \\
\hline & & 1 & 2 & 3 & 4 & 5 & & & \\
\hline 1 & $\begin{array}{l}\text { Saya bersemangat } \\
\text { ketika berbelanja di } \\
\text { Alfamart }\end{array}$ & 0 & 4 & 27 & 55 & 26 & 439 & 3.92 & Baik \\
\hline 2 & $\begin{array}{l}\text { Saya merasa puas ketika } \\
\text { berbelanja di Alfamart }\end{array}$ & 5 & 11 & 34 & 39 & 23 & 400 & 3.57 & Baik \\
\hline 3 & $\begin{array}{l}\text { Saya merasa senang } \\
\text { saat berbelanja di } \\
\text { Alfamart }\end{array}$ & 3 & 11 & 34 & 45 & 19 & 402 & 3.59 & Baik \\
\hline 4 & $\begin{array}{l}\text { Saya merasa nyaman } \\
\text { berbelanja di Alfamart }\end{array}$ & 3 & 11 & 37 & 43 & 18 & 398 & 3.55 & Baik \\
\hline \multicolumn{8}{|c|}{ Rata-rata } & 3,66 & Baik \\
\hline
\end{tabular}

Sumber : Data Diolah, 2019

Berdasarkan Tabel 7. pernyataan yang memiliki rata-rata terendah dari variabel Positive Emotion adalah "Saya merasa nyaman berbelanja di Alfamart", berarti secara umum responden menganggap belum merasa nyaman berbelanja di Alfamart. Nilai rata-rata tertinggi adalah pernyataan "Saya bersemangat ketika berbelanja di Alfamart", responden bersemangat ketika berbelanja di Alfamart 
Berdasarkan Tabel 8. pernyataan yang memiliki rata-rata terendah dari variabel impulse buying adalah "Ketika berkunjung ke Alfamart, saya membeli produk walau tidak direncanakan sebelumnya.", ketika berkunjung ke Alfamart, responden belum membeli produk tanpa direncanakan sebelumnya. Nilai rata-rata tertinggi adalah "Ketika berkunjung ke Alfamart, saya membeli produk walaupun mungkin tidak sesuai dengan keinginan", ketika berkunjung ke Alfamart, responden membeli produk walaupun mungkin tidak sesuai dengan keinginan.

\section{Tabel 8.}

Deskripsi Jawaban Responden Terhadap Impulse Buying

\begin{tabular}{|c|c|c|c|c|c|c|c|c|c|}
\hline \multirow[t]{2}{*}{ No } & \multirow{2}{*}{ Pernyataan } & \multicolumn{5}{|c|}{$\begin{array}{c}\text { Proporsi Jawaban } \\
\text { Responden }\end{array}$} & \multirow{2}{*}{ Jumlah } & \multirow{2}{*}{ Rerata } & \multirow{2}{*}{ Kriteria } \\
\hline & & 1 & 2 & 3 & 4 & 5 & & & \\
\hline 1 & $\begin{array}{l}\text { Ketika berkunjung ke } \\
\text { Alfamart, saya membeli } \\
\text { produk walau tidak } \\
\text { direncanakan } \\
\text { sebelumnya }\end{array}$ & 0 & 2 & 37 & 54 & 19 & 426 & 3.80 & Baik \\
\hline 2 & $\begin{array}{l}\text { Ketika berkunjung ke } \\
\text { Alfamart, saya tidak } \\
\text { dapat menolak saat ada } \\
\text { tawaran yang menarik }\end{array}$ & 0 & 2 & 29 & 58 & 23 & 438 & 3.91 & Baik \\
\hline 3 & $\begin{array}{l}\text { Ketika berkunjung ke } \\
\text { Alfamart, saya merasa } \\
\text { senang saat melakukan } \\
\text { pembelian yang tidak } \\
\text { direncanakan } \\
\text { sebelumnya }\end{array}$ & 0 & 1 & 32 & 57 & 22 & 436 & 3.89 & Baik \\
\hline 4 & $\begin{array}{l}\text { Ketika berkunjung ke } \\
\text { Alfamart, saya membeli } \\
\text { produk walaupun } \\
\text { mungkin tidak sesuai } \\
\text { dengan keinginan }\end{array}$ & Rat: & -rata & 26 & 59 & 25 & 443 & 3.96 & Baik \\
\hline
\end{tabular}

Sumber : Data Diolah, 2019

Tabel 9.

Hasil Analisis Jalur Pada Struktur 1

\begin{tabular}{|c|c|c|c|c|c|}
\hline \multirow[t]{2}{*}{ Model } & \multicolumn{2}{|c|}{ Unstandardized Coefficients } & \multirow{2}{*}{$\begin{array}{c}\text { Standardized } \\
\text { Coefficients }\end{array}$} & \multirow[t]{2}{*}{$\mathbf{t}$} & \multirow{2}{*}{ Sig. } \\
\hline & B & Std. Error & & & \\
\hline (Constant) & 0.902 & 0.474 & & 1.901 & 0.060 \\
\hline Sales promotion & 0.328 & 0.111 & 0.284 & 2.964 & 0.004 \\
\hline Store environment & 0.363 & 0.123 & 0.284 & 2.958 & 0.004 \\
\hline$: 0,241$ & & & & & \\
\hline
\end{tabular}


Variabel Sales promotion memiliki koefisien sebesar 0,284 berarti Sales promotion memiliki pengaruh positif terhadap Positive Emotion, ini diartikan apabila sales promotion meningkat maka Positive Emotion juga akan meningkat. Variabel Store environment memiliki koefisien sebesar 0,284.

Tabel 10.

Hasil Analisis Jalur Pada Struktur 2

\begin{tabular}{|c|c|c|c|c|c|}
\hline \multirow{2}{*}{ Model } & \multicolumn{2}{|c|}{$\begin{array}{c}\text { Unstandardized } \\
\text { Coefficients }\end{array}$} & \multirow{2}{*}{$\begin{array}{c}\text { Standardized } \\
\text { Coefficients } \\
\text { Beta } \\
\end{array}$} & \multirow[t]{2}{*}{$\mathbf{T}$} & \multirow[t]{2}{*}{ Sig. } \\
\hline & B & Std. Error & & & \\
\hline (Constant) & 0.345 & 0.273 & & 1.263 & 0.209 \\
\hline Sales promotion & 0.184 & 0.065 & 0.200 & 2.827 & 0.006 \\
\hline Store environment & 0.491 & 0.072 & 0.479 & 6.791 & 0.000 \\
\hline Positive Emotion & 0.238 & 0.054 & 0.297 & 4.383 & 0.000 \\
\hline $\mathrm{R}^{2} \quad: 0.623$ & & & & & \\
\hline
\end{tabular}

Variabel sales promotion memiliki koefisien sebesar 0,200 apabila Sales promotion meningkat maka Impulse buying akan meningkat. Variabel Store environment memiliki koefisien sebesar 0,479 berarti apabila Store environment meningkat maka Impulse buying akan meningkat. Variabel Positive Emotion memiliki koefisien sebesar 0,297 berarti apabila Positive Emotion meningkat maka Impulse buying akan meningkat.

Tabel 11.

Uji Normalitas (One-Sample Kolmogorov-Smirnov)

\begin{tabular}{cc}
\hline Persamaan & Kolmogorov-Smirnov Z \\
& \\
\hline Substruktur 1 & 0,570 \\
Substruktur 2 & 0,106 \\
\hline
\end{tabular}

Sumber : Data Diolah, 2019

Tabel 12.

Uji Multikolinieritas (Tolerance dan Variance Inflation Factor)

\begin{tabular}{clcc}
\hline \multirow{2}{*}{ Model } & \multicolumn{2}{c}{ Collinearity Statistics } \\
\cline { 3 - 4 } & Sales promotion & Tolerance & VIF \\
\hline \multirow{2}{*}{ Substruktur1 } & Store environment & 0.757 & 1.322 \\
& Sales promotion & 0.757 & 1.322 \\
& Store environment & 0.700 & 1.428 \\
& Positive Emotion & 0.700 & 1.428 \\
& & 0.759 & 1.318 \\
\hline
\end{tabular}

Sumber: Data Diolah, 2019 
Berdasarkan uji normalitas dengan menggunakan One-Sample KolmogorovSmirnov Test yang ditampilkan pada Tabel 11. disimpulkan bahwa model memenuhi asumsi normalitas. Berdasarkan Tabel 12. tersebut menunjukkan bahwa model regresi bebas dari gejala multikoleniaritas.

Tabel 13.

Uji Heteroskedastisitas

\begin{tabular}{clcc}
\hline Persamaan & \multicolumn{1}{c}{ Model } & T & Sig. \\
\hline \multirow{2}{*}{ Substruktur1 } & Sales promotion & -1.080 & 0.282 \\
& Store environment & 1.144 & 0.212 \\
& Sales promotion & -1.007 & 0.316 \\
Substruktur 2 & Store environment & -0.287 & 0.775 \\
& Positive Emotion & -0.871 & 0.386 \\
\hline
\end{tabular}

Sumber : Data Diolah, 2019

Berdasarkan Tabel 13. tersebut, ditunjukkan bahwa masing-masing model memiliki nilai signifikansi lebih besar dari 5\% atau 0,05. Hal ini menunjukkan bahwa variabel bebas yang digunakan pada penelitian ini tidak berpengaruh secara signifikan terhadap variabel terikatnya yaitu absolute error, maka dari itu, penelitian ini bebas darigejala heteroskedastisitas.

Pengaruh antara Sales promotion terhadap Impulse buying dalam penelitian ini diperoleh nilai koefisien Beta sebesar 0,200 dan nilai Sig. sebesar 0,006 maka Sales promotion berpengaruh positif dan signifikan terhadap impluse buying dengan kata lain semakin baik Sales promotion yang dilakukan Alfamart maka impluse buying pada konsumen Alfamart di Kota Denpasar juga akan semakin baik. Hal ini sejalan dengan hasil penelitian yang dilakukan oleh Akyuz (2018), Nishanov dan Ahunjonov (2016), Ismail dan Siddiqui (2019), Kasimin dkk. (2015), Pradipta dan Rastini (2014), Mamuaya dan Pandowo (2018), Maulana (2018) serta Negara dan Kusumadewi (2018) yang menyatakan bahwa sales promotion berpengaruh positif signifikan terhadap impulse buying.

Pengaruh antara Store environment terhadap Impulse buying dalam penelitian ini diperoleh nilai koefisien Beta sebesar 0,479 dan nilai Sig. sebesar 0,000, maka Store environment berpengaruh positif dan signifikan terhadap Impulse buying dengan kata lain semakin baik Store environment maka Impulse buying pada konsumen Alfamart di Kota Denpasar akan semakin baik. Hal ini sejalan dengan hasil penelitian yang dilakukan oleh Nindyakirana dan Maftukhah (2016) ditemukan hasil bahwa terdapat pengaruh secara langsung lingkungan toko terhadap impulse buying yang berarti semakin tinggi lingkungan toko diterapkan maka dapat meningkatkan impulse buying. Penelitian tersebut juga didukung oleh Jhawar dan Kushwaha (2018) yang menyatakan bahwa suasana lingkungan di dalam toko mempengaruhi pembelian impulsif. Hasil penelitian ini juga didukung oleh Saad dan Metawie (2015), Husnain et al. (2019), Prakash dan Sharma (2016), serta Purwa dan Yasa (2014).

Pengaruh antara Sales promotion terhadap Positive Emotion dalam penelitian ini diperoleh nilai koefisien Beta sebesar 0,284 dan nilai Sig. sebesar 
0,004, maka Sales promotion memiliki pengaruh positif dan signifikan terhadap Positive Emotion, dengan kata lain semakin baik Sales promotion yang dilakukan oleh Alfamart di Kota Denpasar, maka semakin baik juga Positive Emotion yang dirasakan oleh Konsumen. Hal ini sejalan dengan hasil penelitian yang dilakukan oleh Idris (2018), menyatakan bahwa promosi penjualan berpengaruh positif dan signifikan terhadap emosi positif. Hal ini didukung juga oleh hasil penelitian dari Akyuz (2018) serta Suwandi dan Soelasih (2014) yang menyatakan bahwa semakin ditingkatkannya promosi penjualan maka akan dapat meningkatkan emosi positif konsumen yang nantinya akan melakukan pembelian secara impulsif atau tidak terencana.

Pengaruh antara Store environment terhadap Positive Emotion dalam penelitian ini diperoleh nilai koefisien Beta sebesar 0,284 dan nilai Sig. sebesar 0,004, maka Store environment memiliki pengaruh positif dan signifikan terhadap Positive Emotion, dengan kata lain semakin baik Store environment yang dilakukan oleh Alfamart di Kota Denpasar, maka semakin baik Positive Emotion yang dirasakan Konsumen. Hal ini sejalan dengan hasil penelitian yang dilakukan oleh Suwandi dan Soelasih (2014) terdapat pengaruh positif lingkungan toko terhadap pembentukan emosi positif konsumen. Volume musik dan aroma yang terdapat di dalam toko dapat meningkatkan emosi pembeli dan juga meningkatkan kepuasan konsumen (Abimnwi dan Njuguna, 2015). Hasil penelitian ini juga didukung oleh Margana dan Setiawan (2014), Nindyakirana dan Maftukhah (2016) serta Putra dan Sukawati (2015).

Pengaruh antara Positive Emotion terhadap Impulse buying dalam penelitian ini diperoleh nilai koefisien Beta sebesar 0,297 dan nilai Sig. sebesar 0.000, maka bahwa Positive Emotion memiliki pengaruh positif dan signifikan terhadap Impulse buying, dengan kata lain apabila Positive Emotion baik maka Impulse buying pada konsumen Alfamart di Kota Denpasar juga akan semakin baik. Hal ini sejalan dengan hasil penelitian yang dilakukan oleh Darmayasa dan Sukaatmadja (2017) serta Gumilang dan Nurcahya (2016).

Tabel 14.

Pengaruh Langsung, Pengaruh Tidak Langsung

\begin{tabular}{lccc}
\hline \multicolumn{1}{c}{ Pengaruh variabel } & $\begin{array}{c}\text { Pengaruh } \\
\text { langsung }\end{array}$ & $\begin{array}{c}\text { Pengaruh tidak } \\
\text { langsung melalui Y1 }\end{array}$ & $\begin{array}{c}\text { Pengaruh } \\
\text { Total }\end{array}$ \\
\hline $\mathrm{X} 1 \rightarrow \mathrm{Y} 1$ & 0,284 & & 0,284 \\
$\mathrm{X} 2 \rightarrow \mathrm{Y} 1$ & 0,284 & & 0,284 \\
$\mathrm{Y} 1 \rightarrow \mathrm{Y} 2$ & 0,297 & 0,297 \\
$\mathrm{X} 1 \rightarrow \mathrm{Y} 2$ & 0,200 & 0,084 & 0,284 \\
$\mathrm{X} 2 \rightarrow \mathrm{Y} 2$ & 0,479 & 0,084 & 0,563 \\
\hline
\end{tabular}

Sumber : Data Diolah, 2019

Peran Positive Emotion dalam memediasi Sales Promotion terhadap Impulse Buying di Alfamart telah diuji dalam penelitian ini. Hasil uji pengaruh Sales 
Promotion terhadap Impulse Buying semula bernilai 0,200, kemudian setelah adanya Positive Emotion sebagai variabel mediasi, nilai pada pengaruh Sales Promotion terhadap Impulse Buying meningkat menjadi sebesar 0,284. Hasil tersebut menunjukkan bahwa Positive Emotion mampu memediasi pengaruh Sales Promotion terhadap Impulse Buying di Alfamart. Penelitian tersebut juga didukung oleh Maulana (2018) serta Nindyakirana dan Maftukhah (2016).

Peran Positive Emotion dalam memediasi Store Environment terhadap Impulse Buying di Alfamart telah diuji dalam penelitian ini. Hasil uji pengaruh Store Environment terhadap Impulse Buying semula bernilai 0,479, kemudian setelah adanya Positive Emotion sebagai variabel mediasi, nilai pada pengaruh Sales Promotion terhadap Impulse Buying meningkat menjadi sebesar 0,563. Hasil tersebut menunjukkan bahwa Positive Emotion mampu memediasi pengaruh Store Environment terhadap Impulse Buying di Alfamart. Hasil penelitian ini juga didukung oleh beberapa penelitian terdahulu lainnya, yaitu Purwa dan Yasa (2014), Negara dan Kusumadewi (2018), Maulana (2018), Margana dan Setiawan (2014).

\section{SIMPULAN}

Sales promotion berpengaruh positif dan signifikan terhadap impulse buying. Hal ini menandakan semakin baik tingkat promosi penjualan maka impulse buying akan baik. Store environment berpengaruh positif dan signifikan terhadap impulse buying. Hal ini menandakan semakin baik lingkungan toko maka impulse buying akan baik. Sales promotion berpengaruh positif dan signifikan terhadap Positive Emotion. Semakin baik tingkat promosi penjualan maka Positive Emotion yang dirasakan konsumen juga akan semakin baik. Store environment berpengaruh positif dan signifikan terhadap Positive Emotion. Hal ini menandakan semakin baik lingkungan toko maka Positive Emotion yang dirasakan konsumen akan semakin baik. Positive Emotion berpengaruh positif dan signifikan terhadap impulse buying. Hal ini menunjukkan semakin baik Positive Emotion yang dirasakan konsumen maka impulse buying akan semakin baik.

Positive Emotion memediasi pengaruh Sales promotion terhadap Impulse buying. Hal ini menunjukkan bahwa semakin baik tingkat promosi penjualan yang dilakukan maka semakin baik impulse buying yang dilakukan oleh konsumen. Selain itu, promosi penjualan juga mampu meningkatkan impulse buying melalui Positive Emotion yang dirasakan oleh konsumen. Positive Emotion memediasi pengaruh Store environment terhadap Impulse buying. Hal ini menunjukkan bahwa semakin baik lingkungan toko maka semakin baik impulse buying yang dilakukan oleh konsumen. Selain itu, lingkungan toko juga mampu meningkatkan impulse buying melalui Positive Emotion yang dirasakan oleh konsumen.

Bagi perusahaan Alfamart sebaiknya lebih sering mengadakan promosi bagi pemegang member card Alfamart, seperti memberikan potongan harga kepada konsumen yang berbelanja dengan menggunakan member card. Promosi tersebut akan dapat menarik perhatian konsumen sehingga dapat meningkatkan pembelian secara tidak terencana serta sebaiknya lebih memperhatikan kenyamanan di dalam toko, seperti penataan produk yang rapi agar konsumen mudah dalam mencari barang, memberikan pelayanan yang ramah dan cepat sehingga konsumen merasa 
lebih nyaman saat berbelanja dan membeli lebih banyak dari yang direncanakan sebelumnya.

\section{REFERENSI}

Abimnwi, N. P., \& Njuguna, R. K. (2015). An Analysis of in Store Environment Ambience Factor Influence on Consumer Behaviour. International Journal of Sales, Retailing \& Marketing, 4(4), 31-44.

Akyuz, A. (2018). Determinaant Factors Influencing Impulse Buying Behavior of Turkish Customers in Supermarket Setting. International Journal of Research in Business and Social Science, 7(1), 1-10.

Chang, H. J., Eckman, R.-N. Y., \& Eckman, M. (2015). Moderating effects of situational characteristics on impulse buying. International Journal of Retail \& Distribution Management, 42(4), 298-314. https://doi.org/10.1108/IJRDM-04-2013-0074

Chih-Yi, W., \& Chien-Ping, C. (2016). The Effects of Store Atmosphere and Sales Promotion on Purchase Intention- Perceived Customer Mood as a Mediator. Business Research Review, 2(1), 33-50.

Choirul, A., \& Artanti, Y. (2019). Millennia's impulsive buying behavior: does Positive Emotion mediate? Achmad. Journal of Economics, Business, and Accountancy Ventura, 22(2), 223-236. https://doi.org/10.14414/jebav.v22i2.1738

Darmayasa, N. M. I. A. A., \& Sukaatmadja, I. P. G. (2017). Analisis Pengaruh Store Atmosphere Dan Sales Promotion Terhadap Emotional Shopping Dan Impulse Buying Behavior. E-Journal Manajemen Unud, 6(11), 6061-6089.

Dewi, K. T., \& Giantari, I. G. A. K. (2015). Peran Emosi Positif Dalam Memediasi Store Atmosphere Terhadap Pembelian Impulsif (Studi Pada Konsumen Matahari Department Store Duta Plaza Denpasar). E-Jurnal Manajemen Unud, 4(12), 4419-4448.

Diany, A. A., Sangen, M., \& Ikhwan Faisal. (2019). Pengaruh Sales Promotion Dan Store Atmosphere Terhadap Positive Emotion Dan Perilaku Impulse Buying Di Departement Store Matahari Duta Mall, Banjarmasin. Wawasan Manajemen, 7(1), 65-84.

Gumilang, W. A., \& Nurcahya, I. K. (2016). Pengaruh Price Discount Dan Store Atmosphere Terhadap Emotional Shopping Dan Impulse Buying. E-Jurnal Manajemen Unud, 15(3), 1859-1888.

Hendra, T. S. K. (2019). How Does The Store ( Mall ) Environment And Money 
Availability Affect Consumer Impulse Buying Behavior At Surabaya City Of Tomorrow Shopping Center? Business Perspectives and Research, 4(2), 215-224.

Husnain, M., Rehman, B., Syed, F., \& Akhtar, M. W. (2019). Personal and Instore Factors Influencing Impulse Buying Behavior among Generation Y Consumers of Small Cities. Business Perspectives and Research, 7(1), 92107. https://doi.org/10.1177/2278533718800625

Idris, A. M. (2018). Analisis Faktor-Faktor Yang Mempengaruhi Emosi Positif Dan Dampaknya Terhadap Pembelian Impulsif Pada Air Asia Indonesia. Diponegoro Journal Of Management, 7(4), 1-9.

Indrawan, I. M. A., \& Sudiksa, I. B. (2019). Pengaruh Store Environment Terhadap Respon Emosi Positif Dan Impulse Buying Yang Dimoderasi Situational Factor. E-Jurnal Manajemen, 8(4), 2071-2097.

Ismail, A., \& Siddiqui, D. A. (2019). Impact of Sales Promotion on Consumer Impulse Purchases in Karachi, Pakistan. SSRN Electronic Journal, 1-31. https://doi.org/10.2139/ssrn.3384158

Jauhari, M. (2017). Pengaruh Promosi, Diskon, Merek, Store Atmosphere, Dan Shopping Emotion Terhadap Impulse Buying Di Kalangan Mahasiswa Fakultas Ekonomi. 003.

Jhawar, N., \& Kushwaha, V. S. (2018). In-Store Shopping Environment and Impulsive Buying with Special Reference to Indore City. IUP Journal of Marketing Management, XVII(1), 26-36.

Kasimin, Dhiana, P., \& Warso, M. M. (2015). Effect Of Discounts, Sales Promotion And Merchandising On Impulse Buying At Toko Intan Purwokerto. Journal of Management, 1(1), 1-19.

Mamuaya, N. C. I., \& Pandowo, A. (2018). The effect of the situational factor, store atmosphere, and sales promotion on hedonic shopping motivation and its implication on supermarket consumer impulsive buying in Manado city. Journal of Business and Retail Management Research, 13(2), 1-11. https://doi.org/10.24052/JBRMR/V13IS02/ART-01

Margana, C. A., \& Setiawan, P. Y. (2014). Pengaruh Stimulus Lingkungan Toko terhadapPerilaku Pembelian Tidak Terencana yang Dimediasi oleh Emosi Positif (Studi Kasus Pada Konsumen Hypermarket di Kota Denpasar). Fakultas Ekonomi Dan Bisnis Universitas Udayana, 3(9), 2615-2632.

Maulana, R. I. (2018). Promosi dan Store Atmosphere Terhadap Shopping Emotion dan Impulse Buying. Jurnal Ecodemica, 2(2). 
Murnawati, \& Khairani, Z. (2018). Store Environmental Atmosphere on Giant Hypermarket Pekanbaru: Do Effect on Consumers Positive Emotion and Impulse? Earth and Environmental Science, 175(1), 7. https://doi.org/10.1088/1755-1315/175/1/012046

Negara, A. A. B. J., \& Kusumadewi, N. M. W. (2018). Pengaruh Atmosfer Ritel Dan Promosi Terhadap Impulse Buying Yang Dimediasi Emosi Positif. EJurnal Manajemen Unud, 7(7), 3944-3973.

Nindyakirana, R. H., \& Maftukhah, I. (2016). Lingkungan toko dan dampaknya terhadap Impulse Buying. Management Analysis Journal, 5(4), 375-388.

Nishanov, B., \& Ahunjonov, U. (2016). The Influence Of Store Characteristics On Consumers' Impulse Buying Behaviour. Journal of International Business Research and Marketing, 1(3), 14-20. https://doi.org/10.18775/jibrm.1849-8558.2015.13.3002

Pradipta, I. N. M. A. W., \& Rastini, N. M. (2014). Pengaruh Atmosfer Toko, Promosi Penjualan, Dan Interaksi Antara Karyawan Toko Dengan Pembeli Terhadap Keputusan Impulse Buying Di Carrefour Hypermarket. Ekonomi Dan Bisnis, 3(8), 2242-2259.

Prakash, A., \& Sharma, A. (2016). Dimensions of point of purchase factors in impulsive buying of women's skincare cosmetics in India. Journal of Business and Retail Management Research, 10(2), 30-44. https://doi.org/10.24052/JBRMR/213

Purwa, E. M. R. G., \& Yasa, N. N. K. (2014). Strategi Store Environment Dan Time Pressure Pada Pembelian Impulsif Melalui Emotional State. Jurnal Dinamika Manajemen, 5(2), 147-160.

Putra, A. D., \& Sukawati, T. G. R. (2015). Peran Emotional Response Konsumen Dalam Memediasi Pengaruh Store Environment Terhadap Impulse Buying ( Survei Pembeli Di Carrefour Kota Denpasar ). E-Jurnal Manajemen Universitas Udayana, 4(1), 75-91.

Rahmadi, M. (2014). Pengaruh Lingkungan Toko Dan Kecenderungan Berbelanja Terhadap Perilaku Pembelian Impuls. Jurnal Manajemen Dan Pemasaran Jasa, 7, 221-246.

Saad, M., \& Metawie, M. (2015). Store Environment, Personality Factors and Impulse Buying Behavior in Egypt: The Mediating Roles of Shop Enjoyment and Impulse Buying Tendencies. Journal of Business and Management Sciences, 3(2), 69-77. https://doi.org/10.12691/jbms-3-2-3 
Sudarsono, J. G. (2017). Pengaruh Visual Merchandising Terhadap Impulse Buying Melalui Positive Emotion Pada Zara Surabaya. Jurnal Manajemen Pemasaran, 11(1), 16-25. https://doi.org/10.9744/pemasaran.11.1.16-25

Suwandi, F. M., \& Soelasih, Y. (2014). Analisis Pengaruh Lingkungan Toko Dan Pengetahuan Produk Terhadap Perilaku Pembelian Impulsif Dengan Emosi Positif Sebagai Mediator Pada Kosmetik Impor Di Indonesia. Portofolio, 11(1), 561-565.

Temaja, I. K. W. B., Rahanata, G. B., \& Yasa, N. N. K. (2015). Pengaruh Fashion Involvement, Atmosfer Toko Dan Promosi Penjualan Terhadap Impulse Buying Pada Matahari Department Store Di Kota Denpasar. E-Jurnal Manajemen Unud, 4(6), 1466-1482.

Utami, C. W. (2010). Manajemen Ritel: Strategi dan Implementasi Operasional Bisnis Ritel Modern di Indonesia. Jakarta: Salemba Empat. 